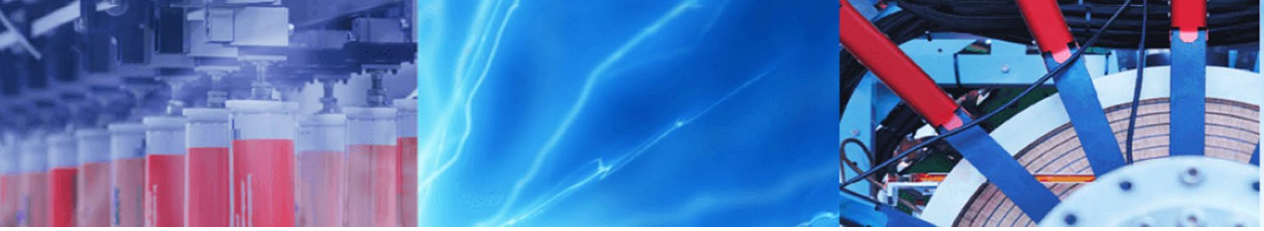

Research Article

\title{
Optimization of Reactive Blue 19 dye removal using ozone and ozone/ UV employing response surface methodology
}

\author{
Mariana Guadalupe Abrile ${ }^{1} \cdot$ María Laura Fiasconaro $^{1} \cdot$ María Eugenia Lovato $^{1}$ D
}

Received: 11 November 2019 / Accepted: 24 April 2020 / Published online: 30 April 2020

(c) Springer Nature Switzerland AG 2020

\begin{abstract}
This work reports the degradation of Reactive Blue 19 (RB19) dye using ozone and ozone/UV. The effects of operational parameters such as $\mathrm{pH}$, ozone concentration and UV radiation were examined. A two factor with three levels factorial design was carried out and the interaction between variables was studied. Response surface methodology was applied in order to optimize ozone concentration, $\mathrm{pH}$ and UV radiation in terms of the half life time required for discoloration and/or mineralization of the solution. Equations of color and TOC half-life time with respect to operational conditions were determined. Contour plots and a desirability function were used to find the local points of optimization. Optimized reaction conditions were established as $\mathrm{pH} 8.26$, UV radiation of $40 \mathrm{~W}$ and ozone concentration of $50 \mathrm{~g} \mathrm{Nm}^{-3}$. A specific experiment was carried out under the optimal conditions where RB19 half life time was 1.59 min and TOC half life time was $30.98 \mathrm{~min}$, confirming the agreement between model and experimental results. The obtained results confirm ozonation as a promising alternative for treatment of wastewater with a high content of recalcitrant reactive dyes.
\end{abstract}

Keywords Ozone · Anthraquinone dye - UV radiation · Reaction modeling · Response surface methodology

\section{Introduction}

Textile industries consume enormous amounts of water, producing large volumes of colored effluents which are finally discharged into water sources, this causes environmental issues related to chemical and biochemical oxygen demand, $\mathrm{pH}$ and salinity.

According to their chemical structure, dyes can be classified into azoic - which constitute the majority group-, anthraquinonic, nitro, indigoid, diphenyl and triphenyl methane, phtalocyanines and polymethines [1]. Anthraquinone dyes are characterized by their high resistance to biodegradation, due to their fused aromatic structures [2-4]. In addition, they could be toxic and cause mutagenic effects on organisms exposed to their effects [5, 6]. Different processes have been used for the treatment of colored effluents, such as adsorption [7], filtration [8, 9], and coagulation [10], among others. However, these treatments have the disadvantage of transferring the contaminant from one phase to another instead of destroying it, consequently the environmental problem persists. For this reason, the need to find destructive treatments arises being the Advanced Oxidation Processes (AOPs) a promissory alternative. AOPs are characterized by achieving a high degree of mineralization of the pollutants, transforming them in water, carbon dioxide and inorganic salts. Although all AOPs have in common the generation of hydroxyl radicals, very reactive and nonselective, they differ in the mechanisms by which these radicals are generated. In the case of ozonation processes, $\mathrm{OH}$ radicals can be formed through different parallel paths, involving other reactive radicals [11, 12]. Ozonation

María Eugenia Lovato, mlovato@santafe-conicet.gov.ar; Mariana Guadalupe Abrile, marianaabrile@gmail.com; María Laura Fiasconaro, mariafiasconaro@gmail.com | ${ }^{1}$ Instituto de Desarrollo Tecnológico para la Industria Química (INTEC), CCT CONICET Santa Fe, Ruta Nacional $\mathrm{N}^{\circ} 168 \mathrm{~km}$ 0, 3000 Santa Fe, Argentina. 
processes are especially effective since they may involve two major active species namely the molecular ozone and the hydroxyl radicals and both species can operate simultaneously [13]. The production of $\mathrm{OH}$ radicals can be increased by the incorporation of UV radiation [14], $\mathrm{H}_{2} \mathrm{O}_{2}$ [15] or increasing the $\mathrm{pH}$ [16]. It is necessary to highlight that both oxidizing species have very different behaviors. While molecular ozone attacks the compounds selectively, $\mathrm{OH}$ radical does so in a non-selective way. Therefore, depending on the molecular structure of the dye, the use of molecular ozone or $\mathrm{OH}$ radical will be more effective. A problem that arises from the use of molecular ozone is related to the formation of resistant intermediates or reaction products which often cannot be degraded by ozone molecules, as is the case of numerous carboxylic acids, aldehydes and ketones [17-19]. The partial oxidation of organic pollutants may result in the production of intermediates even more persistent and toxic than the parent compounds [20]. Although both COD and TOC describe the progress of the oxidation there is a difference between their results: COD is able to measure the change that occurs when the compound is oxidized by ozone, since TOC gives a measure of the mineralization (transformation into carbon dioxide and water) achieved by the ozonation process. For this reason, during the oxidation of a pollutant COD could decrease but the corresponding TOC values could remain almost unchanged. From the environmental point of view, degradation of the dye should be evaluated as an overall process, involving the removal of both the parent dye and its intermediates and products. Therefore, the most suitable resource for estimating the overall process is to monitor the mineralization of the solution through TOC determination.

Numerous studies have reported on the degradation of dyes using photocatalysis [21,22] photo-Fenton and related processes $[23,24]$ and $\mathrm{UV} / \mathrm{H}_{2} \mathrm{O}_{2}$ processes [25], among others.

Although azo dyes are the center of attention of most of the environmental studies, anthraquinone-based dyes also need to be considered as a concern, because of their high resistance to biodegradation. Reactive Blue 19 dye (RB19), well known as Remazol Brilliant Blue is a commercial dye representative of the family of anthraquinone dyes, widely used in the textile industry. Several studies have been reported on the oxidation of RB19 solutions through AOPs. Using an electrochemical-ultrasonics process, Siddique [26] studied the effect of different operational parameters, proposed a reaction mechanism and determined the corresponding kinetic constants. Different authors using a variety of Advanced Oxidation Processes studied the degradation of the dye and the effect of different operational variables, such as $\mathrm{pH}$, initial concentration of RB19 and dose of reagents providing simple kinetic expressions [27-30]. In particular, several studies have successfully carried out the degradation of RB19 through ozonation processes, most of them focusing on the efficiency and kinetics of discoloration [31, 32] and on the effect of operational parameters $[33,34]$ although there exist large discrepancies about the reaction conditions required to achieve discoloration and/or mineralization of the effluents $[4,27,33,34]$. The studies performed by $\mathrm{He}[3]$ and Fanchiang and Tseng [4] are especially significant contributions referred to the identification of intermediaries and the proposal of reaction mechanism for the ozonation of RB19 solutions. In our previous report [20] the effects of operational parameters were investigated and a degradation pathway was proposed for the discoloration and $\mathrm{min}$ eralization of RB19 using ozone and ozone/UV.

According to the literature, a problem that still remains is the need to know the optimal conditions to achieve discoloration, mineralization or a simultaneous combination of both. In order to solve this inquiry, response surface methodology (RSM) can be utilized. This tool consists in a collection of mathematical and statistical techniques useful in the modeling and analysis of situations in which a response is influenced by several variables [35]. Different authors used RSM to establish suitable experimental conditions for the degradation of dyes. Isa [36] used a 3-level factorial design to study the electrochemical degradation of an azoic dye. Moradi et al. [37] and Li et al. [23] utilized a composite central design model for the bleaching of azoic dyes. Debnath et al. [21] employed modified $\mathrm{TiO}_{2}$ for the degradation of two colorants, establishing a factorial design. Akay and Demirtas [38] utilized a central composite design to study the discoloration and COD removal for an azoic dye by means of photo-Fenton treatment, optimizing simultaneously both responses. In the same way, Pillai et al. [39] made use of a Box-Behnken design to perform the simultaneous optimization of the discoloration and mineralization of an azoic model dye by means of an electrochemical process.

Regarding to the optimization of ozonation processes by RSM, there are a much smaller number of reports in the literature. Im et al. [40] utilized a hybrid process $\mathrm{O}_{3} /$ $\mathrm{UV} / \mathrm{H}_{2} \mathrm{O}_{2}$ for the removal of carbamazepine and a central composite design to simultaneously optimize the TOC removal and drug degradation. Vedaraman et al. [41] optimized the ozonation of a tannery model dye using a central composite design. Chianeh and Parsa [42] utilized a combined $\mathrm{O}_{3}$ /electrolysis process for the degradation of an azoic dye, and a composite central design for the optimization of the discoloration, determining the optimal conditions and finally validating them through laboratory experiments. Arslan et al. [43] made use of two different factorial designs to optimize the removal of color and COD of hospital effluents through $\mathrm{O}_{3} / \mathrm{UV}$ and $\mathrm{O}_{3} / \mathrm{H}_{2} \mathrm{O}_{2} /$ 
UV processes. Jiao et al. [44] optimized the degradation of nitrobenzene using a Box-Behnken model and the combined $\mathrm{O}_{3} / \mathrm{H}_{2} \mathrm{O}_{2}$ process. Souza and Féris [45] used a twolevel factorial design to optimize caffeine mineralization through ozonation. Mehrizad and Gharbani [46] developed a central composite design to model the discoloration of a phthalocyanine dye by an $\mathrm{O}_{3} / \mathrm{UV}$ process. From the analysis of literature emerges as first observation that there exists a small number of studies that investigate the ozonation of dyes using RSM, most of them focusing on the degradation of azoic dyes and the optimization of a single variable. As mentioned before, ozone-based technologies involve two major oxidant species that exhibit different oxidizing capacity and selectivity. For this reason, the problem needs to be addressed from two different and complementary points of view in order to achieve the discoloration or mineralization of the solution, where in each of these cases the optimal operating conditions may be very different.

In this work the effect of different operational parameters was investigated in order to find the optimal conditions for discoloration and mineralization of RB19 dye using ozone. RSM was used based on an experimental design and the interaction between variables was studied. Ozone concentration, $\mathrm{pH}$ and UV radiation were optimized in terms of the half life time required for the discoloration and/or mineralization of the solution. The main tasks developed in this work include (1) formulation of the equations of color and TOC half-life time with respect to operational conditions using RSM; (2) determination of the optimum operational condition of the studied application; (3) execution of a specific experiment under optimum conditions to confirm the agreement between model and experimental results.

\section{Materials and methods}

\subsection{Experimental procedures}

\subsubsection{Experimental setup}

The commercial anthraquinone reactive dye RB19 was purchased from Sigma-Aldrich Co., USA and used without any purification. The experimental setup is shown in Fig. 1. Ozone was generated from dried oxygen (Air Liquide Argentina) with purity of $99.2 \%$ using a Fischer 503 ozone generator which can operate in a production range of $0-20 \mathrm{~g} \mathrm{~h}^{-1}$. It was incorporated to the liquid phase with a constant flow rate of $0.4 \mathrm{~L} \mathrm{~min}^{-1}$ (mass flow controller Aalborg GFC17) through an absorption column filled with raschig rings and connected to the atmosphere throughout a purge. The photo-reactor was a cylinder with two parallel flat windows made of quartz, each one irradiated with a tubular lamp (Heraeus NNI $40 \mathrm{~W}, \lambda=253.7 \mathrm{~nm}$, total incident radiation at the reactor wall $\mathrm{G}_{\mathrm{w}}=4.81 \times 10^{-8}$ einstein $\mathrm{cm}^{-2} \mathrm{~s}^{-1}$ ). The system operated in a closed recycle as a perfectly mixed tank reactor and included an ozone monitor for gas phase (Teledyne 454) which operates in the range of $0-200 \mathrm{~g} \mathrm{Nm}^{-3} \pm 1 \%$ and a sampling port. The

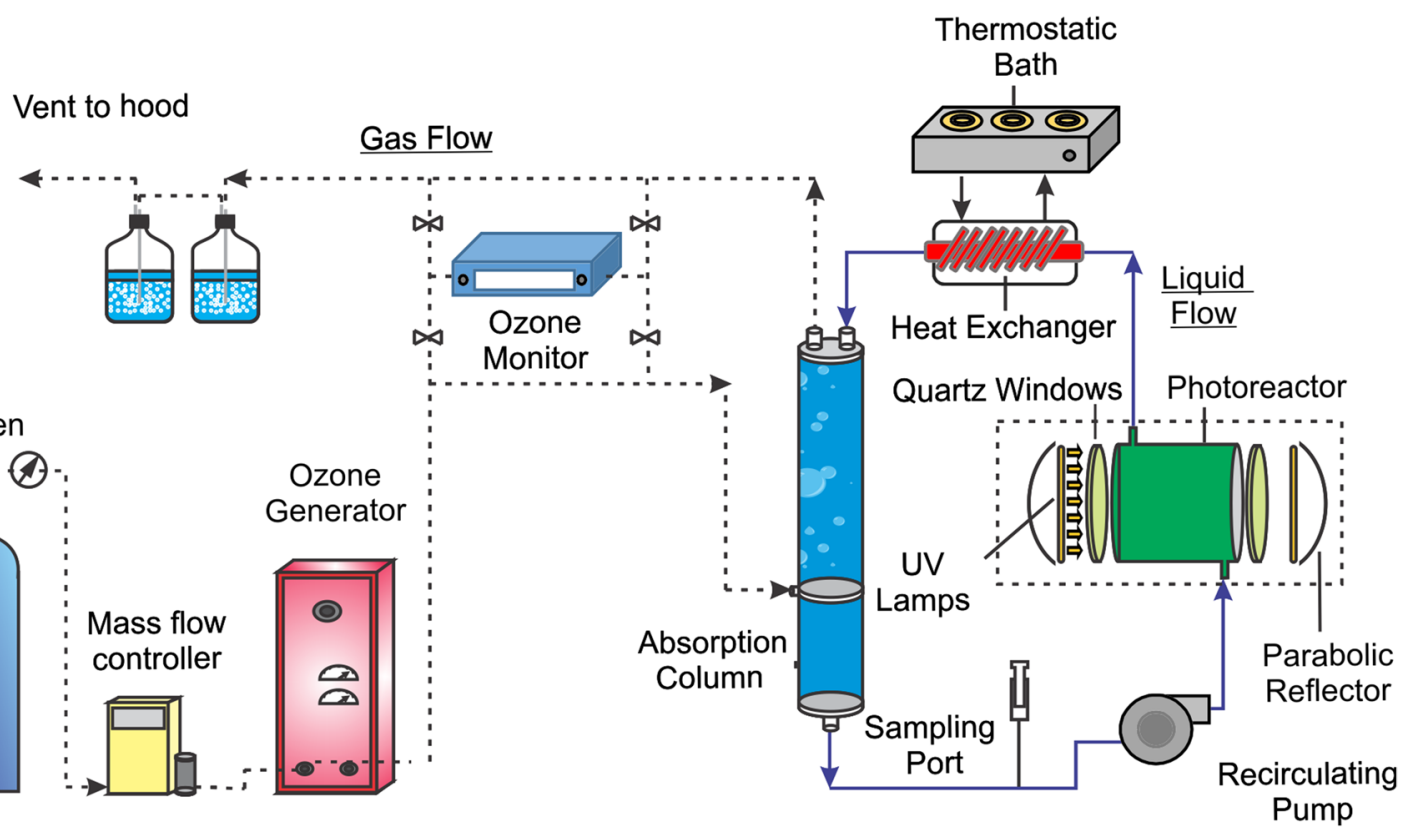

Fig. 1 Experimental setup. Solid lines: liquid flow, dashed lines: gas flow 
experimental setup included a heat exchanger connected to a thermostatic bath to keep constant the reaction temperature $\left(20 \pm 0.1^{\circ} \mathrm{C}\right)$. The total volume was $1.70 \mathrm{~L}$.

\subsubsection{Analyses}

For each experiment, RB19 and Total Organic Carbon (TOC) samples were collected separately at definite time intervals. The concentration of RB19 was determined by UV-vis spectrophotometry (Perkin Elmer) with appropriate calibrations at precise wavelength $(\lambda=592 \mathrm{~nm})$. Preliminary laboratory test were made in order to determine the wavelength at which maximum absorption of the dye takes place. For this purpose, a scanning of RB19 was taken by the spectrophotometer, where two absorbance peaks were found. The peak observed in the UV region at $256 \mathrm{~nm}$ was due to the anthraquinone structure of the dye, while the visible peak at $592 \mathrm{~nm}$ was due to blue color of the chromophore. These results are in concordance with previous reports in which the concentration of RB19 was determined by spectrophotometry $[26,28]$. Total organic carbon (TOC) was measured using a Shimadzu TOC-5000A analyzer. The $\mathrm{pH}$ of the samples was determined using a digital $\mathrm{pH}$ meter (Altronix). All samples analyses were made in triplicate.

\subsection{Design and analysis}

The statistical design of experiments allows for the evaluation of the statistical significance of individual process parameters, as well as the interaction between factors. To optimize RB19 discoloration and mineralization, a threelevel factorial design based on two variables was employed: $\mathrm{pH}\left(\mathrm{X}_{1}\right)$ and inlet Ozone concentration, $\mathrm{O}_{3}^{g, i}\left(\mathrm{X}_{2}\right)$. For two variables and three levels design, 12 experiments were performed including four central points in order to give statistical consistency to the mathematical model. The experimental time required to reach $50 \%$ conversion of $\mathrm{RB} 19$ and Total Organic Carbon ( $\mathrm{t}_{\mathrm{RB} 19_{1 / 2}}$ and $\mathrm{t}_{\mathrm{TOC}_{1 / 2}}$, respectively) were used as response for the experimental design. According to published literature [15] and previous studies [20], the applied ranges of process parameters were: $\mathrm{pH}$ [3-10] and $\mathrm{O}_{3}^{g, i}\left[50-100 \mathrm{gm}^{-3} \mathrm{NTP}\right.$, and for all cases the dye initial concentration was $250 \mathrm{mg} \mathrm{L}^{-1}$. The same procedure was employed to each of UV radiation intensities: $0 \mathrm{~W}$ and $40 \mathrm{~W}$, giving a total of 24 experiments. Table 1 presents the chosen experimental domain, specifying the levels of the factors selected.

Design Expert 7.0 Software was used to make regression for analysis of experimental data and to plot response surface. RSM was applied to evaluate the effect
Table 1 Experimental domain and levels of the selected factors

\begin{tabular}{|c|c|c|}
\hline & \multicolumn{2}{|c|}{ Experimental conditions } \\
\hline & $\begin{array}{l}\text { Experimental } \\
\text { domain }\end{array}$ & Levels \\
\hline UV (W) & $0-40$ & $\begin{array}{l}\text { Without UV radiation/ } \\
\text { with UV radiation } \\
(40 \mathrm{~W})\end{array}$ \\
\hline $\begin{array}{l}\mathrm{O}_{3} \text { inlet }\left(\mathrm{mg} \mathrm{L}^{-1}\right. \\
\text { NTP) }\end{array}$ & $50-100$ & $50,75,100$ \\
\hline $\mathrm{pH}$ & $3-10$ & $3,7,10$ \\
\hline
\end{tabular}

of independent process variables on the discoloration and mineralization efficiency of RB19 by the combined $\mathrm{O}_{3} / \mathrm{UV}$ process. Each level of a factor is combined in the different experiments with all levels of the other factors.

Once the results are obtained for the optimization experiments, a mathematical model is created to describe the relationship between the response and the studied factors. The system's behavior in all cases is represented by a second-order polynomial model.

For each case, the model was fitted to the experimental data and then adopted to describe the response surface, as given below:

$y=\beta_{0}+\beta_{1} X_{1}+\beta_{2} X_{2}+\beta_{11} X_{1}^{2}+\beta_{22} X_{2}^{2}+\beta_{12} X_{1} X_{2}+\varepsilon$

where $y$ is the dependent variable (response), $\beta_{0}$ is a constant, $\beta_{1}$ and $\beta_{2}$ are the regression coefficients for linear effects, $\beta_{11}$ and $\beta_{22}$ are the quadratic coefficients, $\beta_{12}$ is the interaction coefficient, and $\varepsilon$ is the experimental error.

Cook's test was applied to identify the existence of outliers. This test consists of measuring the squared distance between the least squares estimate based on all $n$ points and the estimate obtained when the ith point is removed. If $i$-th point is influential, its removal will result in changing considerably from the value. A Cook distance value greater than 1 would indicate that the point is influential [35]. Outlier points with high leverage and Cook's distance are recommended to be eliminated of the model in order to correctly explain the variation in the data and obtain a better fit [47]. When outlier points were identified, they were eliminated and the model statistical parameters like lack of fit, standard deviation, $R^{2}$ and adjusted $R^{2}$ improved in all the cases.

Process optimization was carried out through the desirability function, with the objective of minimizing the responses using the minimum ozone concentration, leading to a reduction in operating costs. As shown in a previous work [20] the concentration of RB19 is totally reduced when TOC half-life times are accomplished in all the studied experimental conditions. Consequently, the 
optimization is performed based on the simultaneous minimization of $\mathrm{t}_{\mathrm{TOC}_{1 / 2}}$ and $\left[\mathrm{O}_{3}\right]$.

\section{Results and discussion}

\subsection{Screening experiments}

Two groups of controlling runs were made to investigate the eventual effect of $\mathrm{pH}$ and UVC radiation separately: (a) Three solutions of $\mathrm{RB} 19\left(\mathrm{C}_{\mathrm{RB} 19}^{\circ}=250 \mathrm{ppm}\right)$ were prepared at different $\mathrm{pHs}(3,7,10)$ with phosphate buffer and recirculated under normal experimental conditions. In all cases, no degradation was observed for RB19, demonstrating that reaction $\mathrm{pH}$ does not affect the stability of the dye; (b) An experimental run $\left(\mathrm{C}_{\mathrm{RB} 19}^{\circ}=99 \mathrm{ppm}\right)$ was made to evaluate direct photolysis of RB19 (Heareus NNI 40/20 lamps, $\lambda=253.7 \mathrm{~nm})$. RB19 conversion $X_{R B 19}=\left(C_{\mathrm{RB} 19}^{\circ}-\mathrm{C}_{\mathrm{RB} 19}\right) / \mathrm{C}_{\mathrm{RB} 19}^{\circ}$ was null after $2 \mathrm{~h}$, indicating that direct photolysis of RB19 is negligible for the conditions studied in this research.

\subsection{Process optimization in absence of UV radiation}

Previous publications $[3,20,42,48,49]$ have demonstrated that the ozonation process is highly influenced by specific operating variables such as temperature, $\mathrm{pH}$ and UV radiation. In this section, the ozonation in absence of UV radiation will be analyzed. A two factor with three levels design was carried out, including three central point replicates (Table 2). All experiments were performed in random order to avoid introducing a bias on the measurements produced by uncontrolled (or external) factors.

The eventual objective of RSM is to determine the optimum operating conditions for the system or to determine a region of the factor space in which operating specifications are satisfied [35]. For this study, optimization was related to the achievement of two concurrent objectives: a good removal of pollutants and a reduction in operating costs. Costs are related to concentration of ozone, treatment times and use of $\mathrm{pH}$ controlling agents.

To help visualizing the shape of a response surface, the contours of the response surface were plotted. In the contour plot, lines of constant response were drawn in the $\mathrm{X}_{1}, \mathrm{X}_{2}$ plane. Each contour corresponds to a particular height of the response surface. The contour plot is helpful in studying the levels of $x 1$ and $x 2$ that result in changes in the shape or height of the response Surface [35]. For this case, it was useful for identifying different combinations of independent variables $\left(\mathrm{O}_{3}\right.$ and $\left.\mathrm{pH}\right)$ in which satisfactory pollutant removals are achieved, expressed by low half-life of TOC and color.
Table 2 Design matrix and levels based on the factorial design for $\mathrm{O}_{3}$ process

\begin{tabular}{|c|c|c|c|c|c|}
\hline \multirow[t]{2}{*}{ Std } & \multirow[t]{2}{*}{ Run } & \multicolumn{2}{|c|}{ Experimental conditions } & \multicolumn{2}{|c|}{$\begin{array}{l}\text { Experimental response } \\
\text { values }\end{array}$} \\
\hline & & $\begin{array}{l}\mathrm{O}_{3} \text { inlet concen- } \\
\text { tration } \text { (mg L }^{-1} \\
\text { NTP) }\end{array}$ & $\mathrm{pH}$ & $t_{R B 19_{1 / 2}}(\min )$ & $\mathrm{t}_{\mathrm{TOC}_{1 / 2}}(\mathrm{~min})$ \\
\hline 7 & 1 & 50.00 & 10.00 & 1.76 & 33.71 \\
\hline 9 & 2 & 100.00 & 10.00 & 1.48 & 25.50 \\
\hline 1 & 3 & 50.00 & 3.00 & 1.38 & 44.88 \\
\hline 10 & 4 & 75.00 & 7.00 & 1.30 & 78.00 \\
\hline 2 & 5 & 75.00 & 3.00 & 1.30 & $75.80^{\mathrm{a}}$ \\
\hline 11 & 6 & 75.00 & 7.00 & 1.27 & 80.00 \\
\hline 3 & 7 & 100.00 & 3.00 & 1.12 & 26.50 \\
\hline 5 & 8 & 75.00 & 7.00 & 1.32 & 66.00 \\
\hline 4 & 9 & 50.00 & 7.00 & 1.45 & 100.00 \\
\hline 6 & 10 & 100.00 & 7.00 & $1.14^{\mathrm{a}}$ & 73.50 \\
\hline 8 & 11 & 75.00 & 10.00 & 1.62 & 40.67 \\
\hline 12 & 12 & 75.00 & 7.00 & 1.25 & 72.72 \\
\hline
\end{tabular}

${ }^{\mathrm{a} O u t l i e r}$

\subsubsection{Half-life time for color and TOC removal models}

After applying the Cook's test [35] to remove the outliers from Table 2, $\mathrm{t}_{\mathrm{RB}_{19_{1 / 2}}}$ and $\mathrm{t}_{\mathrm{TOC}_{1 / 2}}$ were fitted to quadratic models $\left(Q_{1}\right.$ and $Q_{2}$, respectively). Multiple regression analysis was used to calculate the model coefficients and the analysis of variance (ANOVA) with $95 \%$ confidence level to validate them, resulting in the following expressions:

$t_{R B 19_{1 / 2}}=1.7288-5.700 \times 10^{-3}\left[\mathrm{O}_{3}\right]-0.052 p H+8.422 \times 10^{-3} p H^{2}$

$t_{\text {TOC }_{1 / 2}}=-48.945-0.287\left[\mathrm{O}_{3}\right]+46.114 p H-3.574 p H^{2}$

In both equations, $\left[\mathrm{O}_{3}\right]^{2}$ and $\left[\mathrm{O}_{3}\right] \times p H$ terms were not taken into account because them where non-significant, based on their $p$ value greater than 0.05 (Tables 3, 4). The ANOVA for the quadratic polynomials in Eqs. (2) and (3) confirmed the adequacy of the models.

The signs of the factor terms in Eqs. (2) and (3) provide physical significance to the obtained results. For instance, for color removal, Eq. (2) shows that larger $\mathrm{O}_{3}$ concentration values would result in a lower half-life time for discoloration of the dye, demonstrating the importance of its role in the ozonation reaction. Regarding $\mathrm{pH}$ effect, the linear term indicates that low $\mathrm{pH}$ values result in a shorter half-life time for bleaching. However, the quadratic term presents the opposite effect: it "softens" the effect of the linear term, even causing an increase in the discoloration half-life time for very high $\mathrm{pH}$ values. The model is consistent with previous reports 
Table 3 Estimated effects, coefficients and ANOVA results for $\mathrm{Q}_{1}$ model

\begin{tabular}{|c|c|c|c|c|c|}
\hline \multirow[t]{2}{*}{ Factors } & \multicolumn{5}{|l|}{ Statistics } \\
\hline & SS & $d f$ & MS & F value & $p$ value \\
\hline Model & 0.34 & 3 & 0.11 & 231.27 & $<0.0001$ \\
\hline $\mathrm{O}_{3}$ & 0.097 & 1 & 0.097 & 197.77 & $<0.0001$ \\
\hline $\mathrm{pH}$ & 0.24 & 1 & 0.24 & 486.96 & $<0.0001$ \\
\hline $\mathrm{pH}^{2}$ & 0.027 & 1 & 0.027 & 54.78 & 0.0001 \\
\hline Residual & $3.45 \times 10^{-3}$ & 7 & $4.929 \times 10^{-4}$ & & \\
\hline Lack of fit & $1.215 \times 10^{-3}$ & 4 & $7.938 \times 10^{-4}$ & 8.66 & 0.0536 \\
\hline Pure error & $2.750 \times 10^{-4}$ & 3 & $9.167 \times 10^{-5}$ & & \\
\hline Total & 0.35 & 10 & & & \\
\hline Source of variations & SS & $d f$ & MS & F value & $p$ value \\
\hline Regression & 0.34 & 3 & 0.11 & 231.81 & $<0.0001$ \\
\hline Residual error & $3.450 \times 10^{-3}$ & 7 & $4.929 \times 10^{-4}$ & & \\
\hline Total & 0.35 & 10 & & & \\
\hline $\mathrm{R}^{2}$ & & & & & Pred. $\mathrm{R}^{2}$ \\
\hline 0.9900 & & & & & 0.9711 \\
\hline
\end{tabular}

SS sum of squares, $d f$ degrees of freedom, MS mean square

Table 4 Estimated effects, coefficients and ANOVA results for $\mathrm{Q}_{2}$ model

\begin{tabular}{|c|c|c|c|c|c|}
\hline \multirow[t]{2}{*}{ Factors } & \multicolumn{5}{|l|}{ Statistics } \\
\hline & SS & $d f$ & MS & $\mathrm{F}$ & $p$ \\
\hline Model & 5347.67 & 3 & 1782.56 & 50.29 & $<0.0001$ \\
\hline $\mathrm{O}_{3}$ & 309.46 & 1 & 309.46 & 8.73 & 0.0213 \\
\hline $\mathrm{pH}$ & 6.89 & 1 & 6.89 & 0.19 & 0.6725 \\
\hline $\mathrm{pH}^{2}$ & 5006.00 & 1 & 5006.00 & 141.24 & $<0.0001$ \\
\hline Residual & 248.10 & 7 & 35.44 & & \\
\hline Lack of fit & 172.92 & 4 & 43.23 & 1.73 & 0.3412 \\
\hline Pure error & 75.18 & 3 & 25.06 & & \\
\hline Total & 5595.77 & 10 & & & \\
\hline Source of variations & SS & $d f$ & MS & $F$ value & $p$ value \\
\hline Regression & 5347.67 & 3 & 1782.56 & 50.29 & $<0.0001$ \\
\hline Residual & 248.10 & 7 & 35.44 & & \\
\hline Total & 5595.77 & 10 & & & \\
\hline $\mathrm{R}^{2}$ & & & & & Pred. $\mathrm{R}^{2}$ \\
\hline 0.9557 & & & & & 0.8900 \\
\hline
\end{tabular}

SS sum of squares, $d f$ degrees of freedom, MS mean square

[27], where it was observed that the lowest half-life time for discoloration of RB19 corresponds to $\mathrm{pH} 3$. Molecular ozone is a very effective oxidizing agent for discoloration since it attacks conjugated double bonds that are often associated with color in the dye molecule. Decomposition of ozone into hydroxyl radicals was favored at basic conditions, which was initiated by hydroxyl ions
$\left(\mathrm{OH}^{-}\right)$. Our results indicate that ozone molecules oxidize chromophore molecules of RB19 more effectively than hydroxyl radical would on these molecules. These results are in concordance with our previous report [20] and with Liu [29], who demonstrated that the bleaching ability of ozone was higher at low $\mathrm{pH}$ for certain dyes. 
According to Eq. (3), it can be seen that higher $\mathrm{O}_{3}$ concentration values result in a lower half-life time for mineralization of RB19. Regarding $\mathrm{pH}$ effect, the quadratic term $\mathrm{pH}^{2}$, which has the higher $\mathrm{F}$ value (Table 4) indicates that high $\mathrm{pH}$ values result in lower half-life time for TOC removal, due to the increased concentration of non-selective and highly reactive $\mathrm{OH}$ radicals.

In addition to the regression coefficient, the residuals play an important role in judging model adequacy. A check of the normality assumption could be made by constructing a normal probability plot of the residuals. For $\mathrm{Q}_{1}$ model, Fig. 2a shows normal probability plot of the
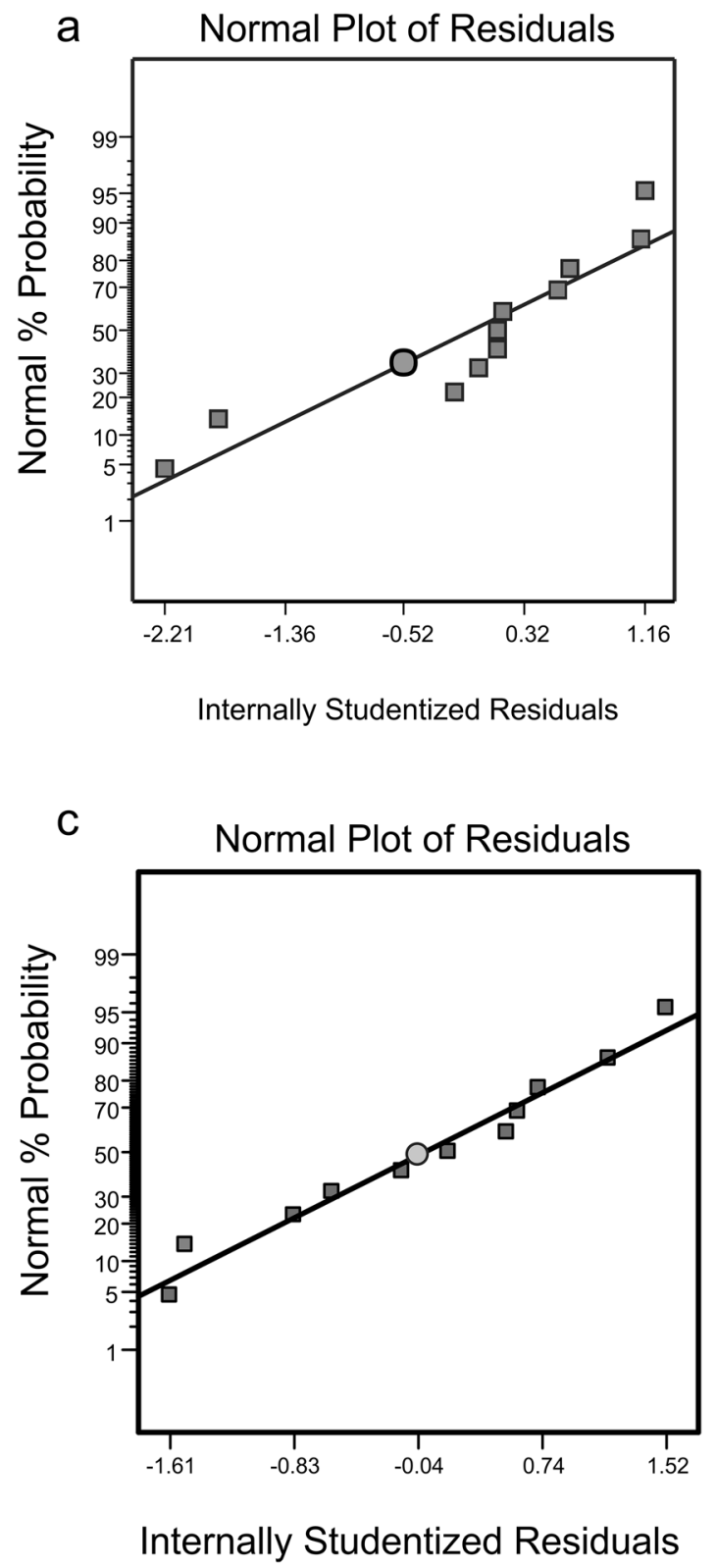

residuals. If the underlying error distribution is normal, the plot will resemble a straight line, and the normality assumption is satisfied. Figure $2 \mathrm{~b}$ presents a plot of residuals versus the predicted values. It shows that the residuals are randomly scattered around zero. Figure $2 \mathrm{c}$, d show the proper for TOC removal $\left(Q_{2}\right.$ model).

\subsubsection{Influence of variables}

The overall effects can be observed in Fig. 3. Figure 3a shows the response surface obtained using $Q_{1}$ model for the ozonation of RB19 solutions in absence of UV
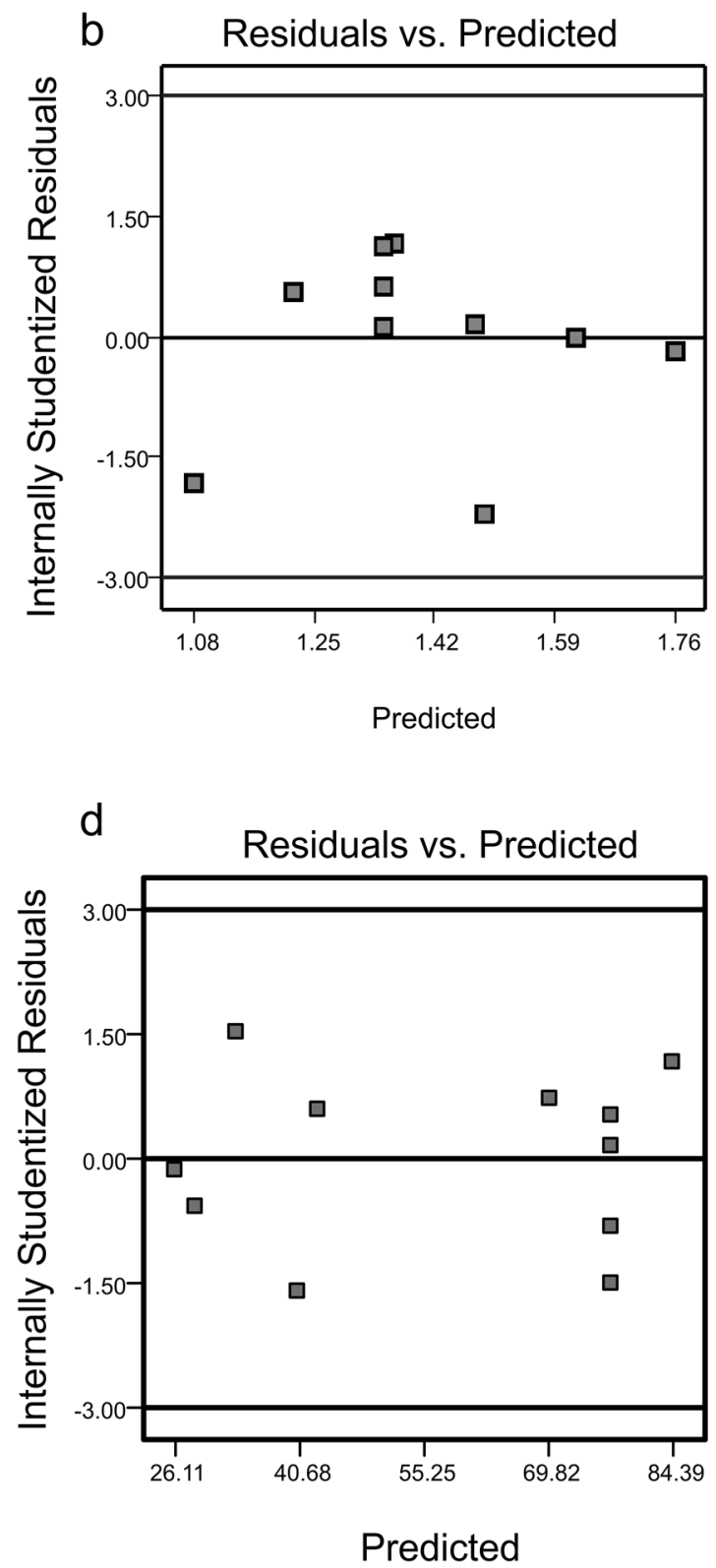

Fig. 2 a Normal probability plot of the residuals for $Q_{1}$. b Residuals versus predicted values plot for $Q_{1}$. c Normal probability plot of the residuals for $Q_{2}$. d Residuals versus predicted values plot for $Q_{2}$ 

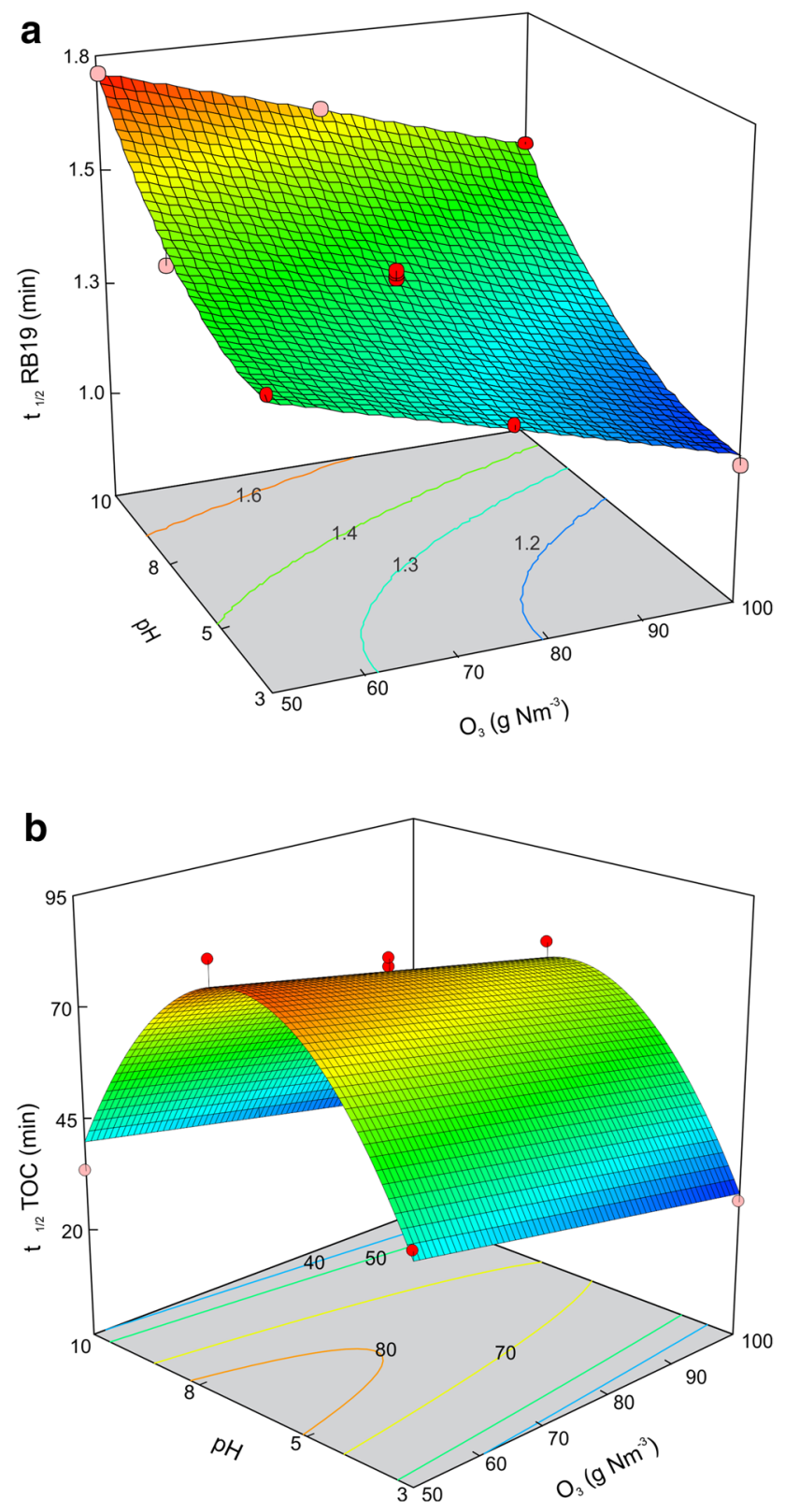

Fig. 3 Response Surface of color and TOC removal as function of $\mathrm{O}_{3}$ concentration and $\mathrm{pH}$. a Color removal-Q1 model. b TOC removal $-\mathrm{Q}_{2}$ model. (Circle) Experimental data

radiation. According to the shape of the surface, the lower $t_{\mathrm{RB}_{191 / 2}}$ values are those corresponding to lower $\mathrm{pH}$ values and higher $\left[\mathrm{O}_{3}^{g, i}\right]$. As can be observed, keeping inlet ozone concentration constant $\left(50,75\right.$ or $\left.100 \mathrm{mg} \mathrm{L}^{-1} \mathrm{NTP}\right)$ and increasing $\mathrm{pH}, \mathrm{t}_{\mathrm{RB} 19_{1 / 2}}$ becomes higher. On the other hand it can be observed that higher operating ozone concentrations result in lower half-life time values. It can be noticed that lower $\mathrm{pH}$ 's would compensate a lower inlet ozone concentration, which is important from an economical point of view. This is due to the control exerted by the $\mathrm{pH}$ on the relative concentrations of ozone and hydroxyl radicals. At acidic $\mathrm{pH}$, the presence of molecular ozone is favored, which is the most effective species for the selective removal of the RB19 dye. At alkaline $\mathrm{pH}$, the concentration of molecular ozone decreases by its decomposition into hydroxyl radicals, which must be compensated by an increase in ozone at the entrance, causing a rise in operating costs.

The lowest half-life time (1.12 $\mathrm{min})$, which results in the highest decolorization efficiency was achieved for run \#7 ( $\mathrm{pH} 3$ and $\mathrm{O}_{3}=100 \mathrm{mg} \mathrm{L}^{-1} \mathrm{NTP}$ ). Conversely, the maximum half-life time (1.76 min, Run \#1) was obtained when the highest $\mathrm{pH}$ value (10) and lowest ozone concentration (50 $\mathrm{mg} \mathrm{L}^{-1}$ NTP) were used. At this $\mathrm{pH}$ value, an important decrease (16\%) of color half-life time is observed when $\mathrm{O}_{3}^{g, i}$ dose is doubled (1.48 min in run \#2). The same tendency can be observed when $\mathrm{O}_{3}^{g, i}$ is kept at its lowest value and $\mathrm{pH}$ is reduced (1.38 min in run \#1), but in this case the half life time reduction (22\%) is higher. This observation is in accordance with the $\mathrm{F}$ values gathered by the ANOVA of $\mathrm{Q}_{1}$ model for $\mathrm{pH}$ and $\mathrm{O}_{3}$ (486.96 and 197.77 in Table 3, respectively), showing the higher influence of the former in the model predictions.

In Fig. $3 \mathrm{~b}$ the effect of ozone concentration and $\mathrm{pH}$ on TOC half-life time is shown. It can be observed that halflife time decreases with the increase of ozone concentration. As is also clear from the figure, TOC removal half-life time exhibits a maximum at $\mathrm{pH} 7$ for all the studied $\mathrm{O}_{3}^{g, i}$. This could be explained taking into account that low $\mathrm{pH}$ values favored color removal, but the generation of the non-selective $\mathrm{OH}$ radicals becomes more important when $\mathrm{pH}$ is raised. The lowest TOC half-life time was observed in run \#2 ([O $\left.\left.\mathrm{O}_{3}\right]=100 \mathrm{mg} \mathrm{L}^{-1} \mathrm{NTP}, \mathrm{pH} 10\right)$. This result could be attributed to the enhanced concentration of $\mathrm{OH}$ radicals in the solution at high $\mathrm{pH}$ values. The highest TOC half-life time is the corresponding to run \#9 $\left(\left[\mathrm{O}_{3}\right]=50 \mathrm{mg} \mathrm{L}^{-1} \mathrm{NTP}\right.$, $\mathrm{pH}$ 7). Although molecular ozone is a powerful oxidant, it is known that it could be insufficient for the oxidation of intermediates resulting from the oxidation of the dye. The lower TOC removals at acidic conditions can be explained by this fact, showing that the most efficient mineralization conditions are those with high $\mathrm{O}_{3}$ concentrations and high $\mathrm{pH}$ values, where hydroxyl radicals' formation is favored.

\subsection{Process optimization under UV radiation}

Once more, a two factor with three levels design was carried out. The design consisted of 12 experiments with independent combinations of variables, including three central point replicates (Table 5). After removing the outliers, the dye half-life time for decolorization and mineralization were fitted to quadratic models $\left(\mathrm{Q}_{3}\right.$ and $\left.\mathrm{Q}_{4}\right)$. Multiple regression analysis was used to calculate the model 
Table 5 Design matrix and levels based on the factorial design for $\mathrm{O}_{3} / \mathrm{UV}$ process

\begin{tabular}{|c|c|c|c|c|c|}
\hline \multirow[t]{2}{*}{ Std } & \multirow[t]{2}{*}{ Run } & \multicolumn{2}{|c|}{ Experimental conditions } & \multicolumn{2}{|c|}{$\begin{array}{l}\text { Experimental response } \\
\text { values }\end{array}$} \\
\hline & & $\begin{array}{l}\mathrm{O}_{3} \text { inlet concen- } \\
\text { tration }\left(\mathrm{mg} \mathrm{L}^{-1}\right. \\
\text { NTP) }\end{array}$ & $\mathrm{pH}$ & $t_{R B 19_{1 / 2}}(\min )$ & $\mathrm{t}_{\mathrm{TOC}_{1 / 2}}(\mathrm{~min})$ \\
\hline 6 & 1 & 100.00 & 7.00 & 1.40 & 26.74 \\
\hline 10 & 2 & 75.00 & 7.00 & 1.52 & 27.40 \\
\hline 3 & 3 & 100.00 & 3.00 & 1.25 & $33.02^{\mathrm{a}}$ \\
\hline 11 & 4 & 75.00 & 7.00 & 1.54 & 27.50 \\
\hline 9 & 5 & 100.00 & 10.00 & 1.65 & 30.40 \\
\hline 2 & 6 & 75.00 & 3.00 & 1.34 & 41.16 \\
\hline 8 & 7 & 75.00 & 10.00 & 1.75 & 29.74 \\
\hline 4 & 8 & 50.00 & 7.00 & 1.63 & $55.60^{\mathrm{a}}$ \\
\hline 12 & 9 & 75.00 & 7.00 & 1.52 & 27.00 \\
\hline 5 & 10 & 75.00 & 7.00 & 1.55 & 27.60 \\
\hline 1 & 11 & 50.00 & 3.00 & 1.55 & 45.36 \\
\hline 7 & 12 & 50.00 & 10.00 & 1.93 & 30.47 \\
\hline
\end{tabular}

${ }^{\mathrm{a} O u t l i e r s}$

coefficients and the analysis of variance (ANOVA) with $95 \%$ confidence level to validate them.

\subsubsection{Half-life time for color and TOC removal models}

In order to evaluate the influence of two variables $(\mathrm{pH}$ and $\mathrm{O}_{3}$ ) and to optimize RB19 decolorization and mineralization through the application of the ozonation process with
UV radiation $(40 \mathrm{~W})$, it was employed a similar methodology that for the case of absence of UV radiation. The application of multiple regression analysis on the experimental conditions resulted in the quadratic models $\mathrm{Q}_{3}$ and $\mathrm{Q}_{4}$ for color and TOC half-life time, respectively:

$$
\begin{aligned}
t_{R B 19_{1 / 2}}= & 1.815-5.367 \times 10^{-3}\left[\mathrm{O}_{3}\right]-0.031 p H+6.736 \times 10^{-3} \mathrm{pH}^{2} \\
t_{T O C_{1 / 2}}= & 85.665-0.380\left[\mathrm{O}_{3}\right]-10.909 p H+0.019\left[\mathrm{O}_{3}\right] \\
& \times p H+1.248 \times 10^{-3}\left[\mathrm{O}_{3}\right]^{2}+0.602 p H^{2}
\end{aligned}
$$

In Eq. (4), $\left[\mathrm{O}_{3}\right]^{2}$ and $\left[\mathrm{O}_{3}\right] \times p H$ terms were not taken into account because them where non-significant, based on their $p$ value greater than 0.05 , while in Eq. (5) all terms were included, according to their $p$ value (Tables 6,7$)$.

The impact of each independent variable in the oxidation process is attributable directly to its coefficient. From Eq. (4), the negative contribution of $\mathrm{O}_{3}$ to the half-media time for decolorization is observed, while the positive coefficient value of $\mathrm{pH}^{2}$ suggests that higher $\mathrm{pH}$ values increase the half-life time of color, such as in $\mathrm{Q}_{1}$ model. From Eq. (5), the negative signs of $\mathrm{C}_{\mathrm{O} 3}$ and $\mathrm{pH}$ coefficients suggest that higher $\mathrm{O}_{3}$ concentrations and $\mathrm{pH}$ values reduce the half-life time for TOC removal. But $\mathrm{pH}^{2}$ term has a high $\mathrm{F}$ value (Table 7) that indicates that the $\mathrm{pH}$ effects exhibits a parabolic shape. The lower mineralization half-life times are those corresponding to $\mathrm{pH} 7$, just the opposite than the observations made in absence of UV

\begin{tabular}{|c|c|c|c|c|c|}
\hline \multirow[t]{2}{*}{ Factors } & \multicolumn{5}{|l|}{ Statistics } \\
\hline & SS & $d f$ & MS & $\mathrm{F}$ & $p$ \\
\hline Model & 0.35 & 3 & 0.12 & 151.93 & $<0.0001$ \\
\hline $\mathrm{O}_{3}$ & 0.11 & 1 & 0.11 & 139.74 & $<0.0001$ \\
\hline $\mathrm{pH}$ & 0.24 & 1 & 0.24 & 305.36 & $<0.0001$ \\
\hline $\mathrm{pH}^{2}$ & 0.019 & 1 & 0.019 & 25.11 & 0.0010 \\
\hline Residual & $6.18 \times 10^{-3}$ & 8 & $7.729 \times 10^{-4}$ & & \\
\hline Lack of fit & $1.215 \times 10^{-3}$ & 5 & $1.102 \times 10^{-3}$ & 4.90 & 0.1107 \\
\hline Pure error & $5.508 \times 10^{-3}$ & 3 & $2.250 \times 10^{-4}$ & & \\
\hline Total & 0.36 & 11 & & & \\
\hline Source of variations & SS & $d f$ & MS & $F$ value & $p$ value \\
\hline Regression & 0.35 & 3 & 0.12 & 151.93 & $<0.0001$ \\
\hline Residual & $6.18 \times 10^{-3}$ & 8 & $7.73 \times 10^{-4}$ & & \\
\hline Total & 0.36 & 11 & & & \\
\hline $\mathrm{R}^{2}$ & & & & & Pred. $\mathrm{R}^{2}$ \\
\hline 0.9828 & & & & & 0.9547 \\
\hline
\end{tabular}
radiation. This could be explained taking into account that

Table 6 Estimated effects, coefficients and ANOVA results for Q3 model

SS sum of squares, $d f$ degrees of freedom, MS mean square 
Table 7 Estimated effects, coefficients and ANOVA results for $\mathrm{Q}_{4}$ model

\begin{tabular}{|c|c|c|c|c|c|}
\hline \multirow[t]{2}{*}{ Factors } & \multicolumn{5}{|l|}{ Statistics } \\
\hline & SS & $d f$ & MS & $\mathrm{F}$ & $p$ \\
\hline Model & 381.23 & 5 & 76.25 & 1417.71 & $<0.0001$ \\
\hline $\mathrm{O}_{3}$ & 6.57 & 1 & 6.57 & 122.11 & 0.0004 \\
\hline $\mathrm{pH}$ & 102.59 & 1 & 102.59 & 1907.58 & $<0.0001$ \\
\hline $\mathrm{O}_{3} \times \mathrm{pH}$ & 4.56 & 1 & 4.56 & 84.81 & 0.0008 \\
\hline $\mathrm{O}_{3}^{2}$ & 1.10 & 1 & 1.10 & 20.51 & 0.0106 \\
\hline $\mathrm{pH}^{2}$ & 87.08 & 1 & 87.08 & 1619.24 & $<0.0001$ \\
\hline Residual & 0.22 & 4 & 0.054 & & \\
\hline Lack of fit & $7.625 \times 10^{-3}$ & 1 & $7.625 \times 10^{-3}$ & 0.11 & 0.7617 \\
\hline Pure error & 0.21 & 3 & 0.069 & & \\
\hline Total & 381.45 & 9 & & & \\
\hline Source of variations & SS & $d f$ & MS & F value & $p$ value \\
\hline Regression & 381.23 & 5 & 76.25 & 1417.71 & $<0.0001$ \\
\hline Residual & 0.22 & 4 & 0.054 & & \\
\hline Total & 381.45 & 9 & & & \\
\hline $\mathrm{R}^{2}$ & & & & & Pred. $\mathrm{R}^{2}$ \\
\hline 0.9994 & & & & & 0.9972 \\
\hline
\end{tabular}

SS sum of squares, $d f$ degrees of freedom, MS mean square

mineralization is performed by the attack of non-selective $\mathrm{OH}$ radicals, whose production is favored by high $\mathrm{pH}$ values and UV radiation. The presence of UV radiation could compensate $\mathrm{pH}$ effects, and consequently the half-life time exhibits a minimum at neutral pH. At pH 3, the effect of $\mathrm{O}_{3}$ concentration is much more marked than at alkaline $\mathrm{pH}$. This indicates that $\mathrm{pH}$ and UV radiation could compensate for a decrease on the ozone dose.

The ANOVA for the quadratic polynomials in Eqs. (4) and (5) confirmed the adequacy of the models (Tables 6, 7).

For $\mathrm{Q}_{3}$ model, Fig. 4a shows normal probability plot of the residuals, while Fig. $4 \mathrm{~b}$ presents a plot of residuals versus the predicted values. It shows that the residuals are randomly scattered around zero. Figure $4 c$, $d$ show the proper for TOC removal $\left(Q_{4}\right.$ model).

\subsubsection{Influence of variables}

Figure 5a shows that the color removal half-life time decreases with the increase in ozone concentration and the decrease of $\mathrm{pH}$, as was observed for decolorization in absence of UV radiation. The lowest half-life time is reached in the conditions of run \# $3\left(\left[\mathrm{O}_{3}\right]=100 \mathrm{mg} \mathrm{L}^{-1} \mathrm{NTP}\right.$, $\mathrm{pH} 3$ ). In this case, although the tendencies are similar to those without UV radiation, the reached half-life times are higher, indicating that color removal is favored in absence of UV radiation, in concordance with the observed results regarding $\mathrm{pH}$ effect: for the studied dye, molecular ozone is selective and more effective for color removal than $\mathrm{OH}$ radicals. Predicted and experimental results for the mineralization of RB19 using UV radiation are presented in Fig. 5b, which shows the 3D plot of half-life time for RB19 mineralization as a function of $\mathrm{pH}$ and $\mathrm{O}_{3}$ concentration. It is interesting to notice that TOC half-life times are lower in comparison with those required for mineralization in absence of UV radiation. In presence of UV radiation, the formation of non-selective hydroxyl radicals is favored, which results in a significant improvement in the degradation of the reaction intermediaries and therefore, in the mineralization of the solution.

\subsection{Determination of optimal conditions for simultaneous decolorization and mineralization of RB19}

The main objective of RSM optimization is to determine the optimum conditions for RB19 decolorization and mineralization minimizing ozone consumption. Optimization was performed from the obtained model through the calculation of the desirability function using Design Expert software. Desirability values close to 1 correspond to points where the proposed objectives are satisfactorily met. The results obtained for the system with and without UV radiation, trying to simultaneously minimize $\mathrm{t}_{\mathrm{TOC}_{1 / 2}}$ and the inlet ozone concentration are shown in Table 8. 


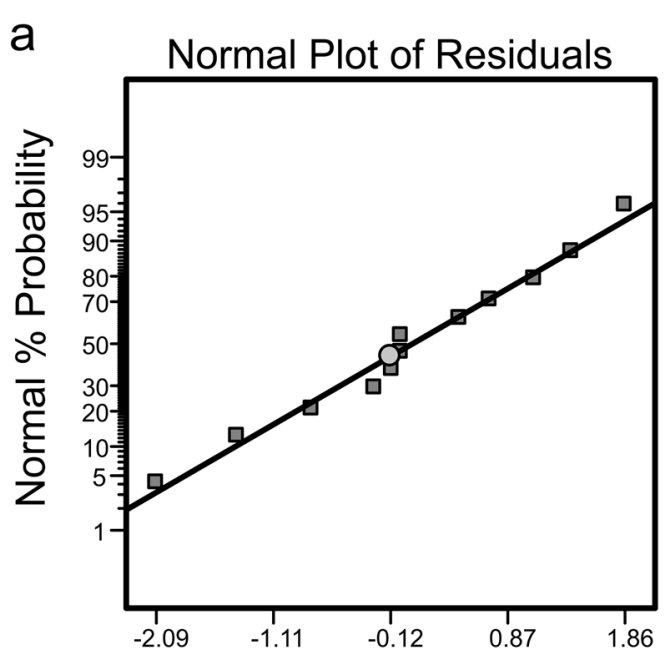

Internally Studentized Residuals

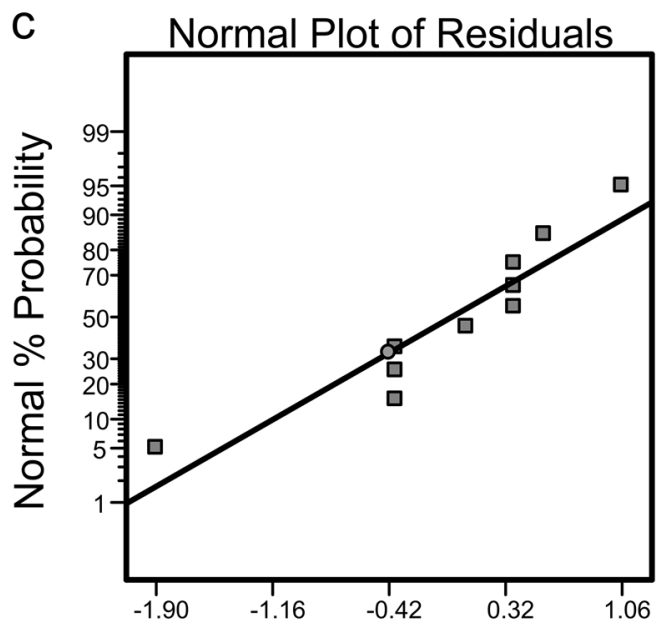

Internally Studentized Residuals

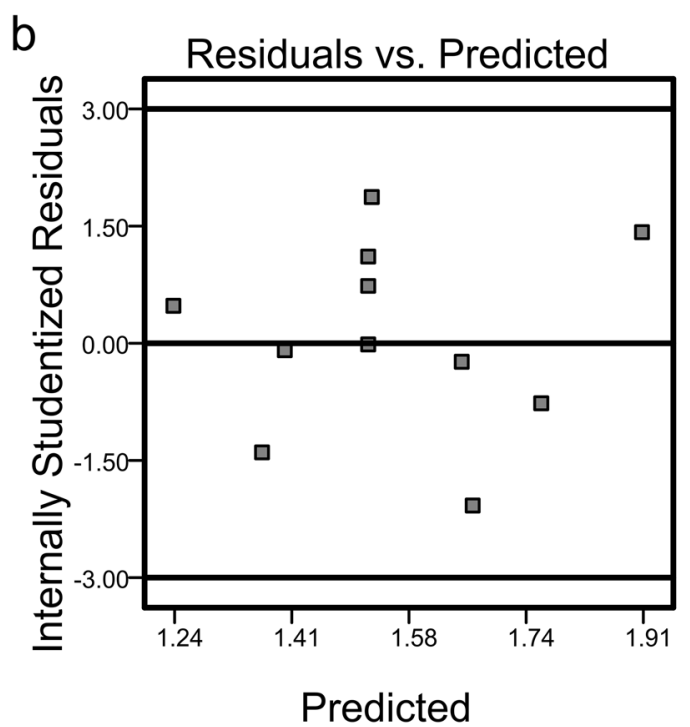

d

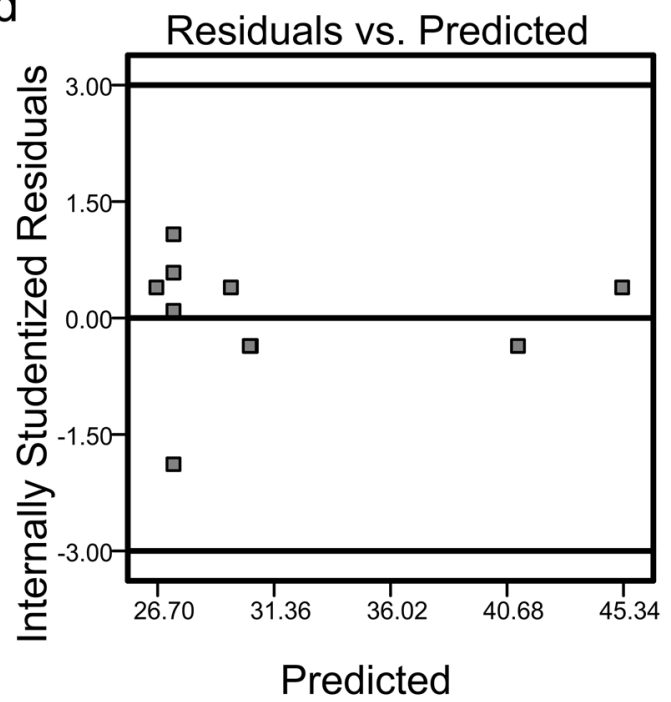

Fig. 4 a Normal probability plot of the residuals for $Q_{3}$. b Residuals versus predicted values plot for $Q_{3}$. c Normal probability plot of the residuals for $\mathrm{Q}_{4}$. d Residuals versus predicted values plot for $\mathrm{Q}_{4}$

As it is observed, the system with radiation allows to obtain the optimum values of work, reaching values of half-life times for TOC of $28.67 \mathrm{~min}$, while for the system without radiation this value is around $40 \mathrm{~min}$.

Through desirability surface graphics (Fig. 6) areas of high desirability are evaluated, allowing identifying regions of operation where results are optimal, in concordance with the objectives pursued. In this way, a large continuous region of high desirability could be observed in the $\mathrm{O}_{3} /$ UV system. According to this observation, it is possible to work in slightly acidic to alkaline conditions and with low inlet ozone concentrations, obtaining a reasonably low value of half-life times for TOC.
Once the optimization was made, specific experimental runs were performed under these optimized conditions to confirm the agreement between the model and experiments. These results also confirm that half-life time for color and TOC removal were correctly predicted by the model.

Figure 7 shows the experimental results of RB19 and TOC, as a function of time for the experiment performed under the optimized conditions for $\mathrm{O}_{3}$ and $\mathrm{O}_{3} / \mathrm{UV}$ systems, respectively. It can be seen that in both systems, the total decolorization of the effluent is quickly reached. However, as regards mineralization, the results obtained by ozonation in conjunction with radiation were superior to those 

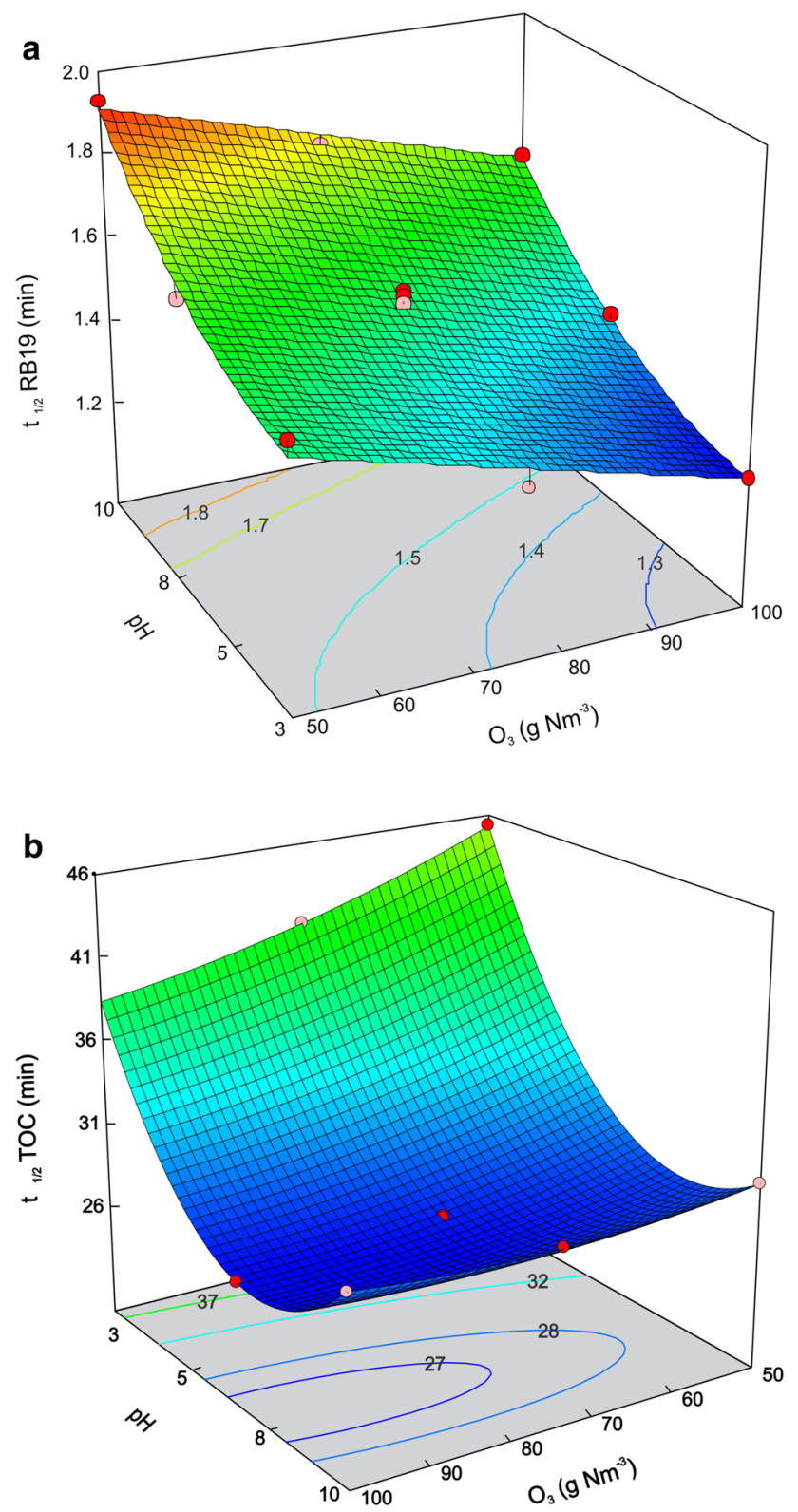

Fig. 5 Response surface of color and TOC removal as function of $\mathrm{O}_{3}$ concentration and $\mathrm{pH}$. a Color removal $-\mathrm{Q}_{3}$ model. $\mathbf{b}$ TOC removal $-\mathrm{Q}_{4}$ model. (Circle) Experimental data of the system without radiation. In the first, a $90 \%$ degradation of the TOC was reached at $70 \mathrm{~min}$, while in the second system, a reaction time of $85 \mathrm{~min}$ was necessary. This phenomenon is related to the increased concentration of hydroxyl radicals. The addition of UV radiation to the system leads to $\mathrm{O}_{3}$ photolysis producing $\mathrm{H}_{2} \mathrm{O}_{2}$, which could react with $\mathrm{O}_{3}$ via hydroperoxide ion or could be photolyzed, producing $\mathrm{OH}$ radicals in both cases [48]. Hydroxyl radicals are highly reactive species that attack most of the organic molecules due to their high oxidation potential and nonselective nature. Consequently, the $\mathrm{UV} / \mathrm{O}_{3}$ system produces additional $\mathrm{OH}$ radicals, which enhance the mineralization process and consequently decreases TOC halflife time. The study of mineralization is really important because, as demonstrated in our previous work [20], for RB19 ozonation in the first minutes the color is completely degraded, however intermediates of greater toxicity are generated. Lovato [34] observed that when the color was completely degraded, TOC conversion reached $2 \%$ and biotoxicity exhibited a maximum of inhibition, becoming $60 \%$ higher than the initial toxicity. This implies that there were toxic intermediates present in the solution. Using GC-MS the following compounds were identified: Anthraquinone; phthalic anhydride; phthalimide; phthalic acid, benzoic acid, maleic acid, benzyl alcohol, benzaldehyde, phenol, aniline, oxalic acid and acetic acid. Regarding the toxicity of parent compounds, intermediates and products, some of the identified degradation products of RB19 (especially phenol and aniline) are more toxic than the parent compound. When mineralization reached $95 \%$, the biotoxicity decreased to $26 \%$ of the initial toxicity, which corresponds to a 100 min treatment under the optimal conditions found in this work.

\subsection{Comparison between simulation results and experimental data}

Figure 8 shows a compendium of the simulation results versus the experimental data, including all the runs performed to carry out this work. In this plot the lines corresponding to the $95 \%$ Confidence interval and the $95 \%$ Prediction limits are included. It can be seen that for such complex system, the agreement is quite satisfactory.

Table 8 Optimized conditions for RB19 discoloration and mineralization

\begin{tabular}{|c|c|c|c|c|c|c|c|}
\hline \multirow{2}{*}{$\begin{array}{l}\mathrm{O}_{3} \text { concentration } \\
\left(\mathrm{mg} \mathrm{L}^{-1}\right)\end{array}$} & \multirow{2}{*}{$\mathrm{pH}$} & \multirow[t]{2}{*}{ UV radiation } & \multicolumn{2}{|c|}{ Model estimation } & \multirow[t]{2}{*}{$\mathrm{D}$} & \multicolumn{2}{|c|}{ Experimental results } \\
\hline & & & Color $_{t_{1 / 2}}(\min )$ & $\mathrm{TOC}_{1 / 2}(\min )$ & & Color $_{1 / 2}(\min )$ & TOC $t_{1 / 2}(\min )$ \\
\hline 50.44 & 10.00 & Without radiation & 1.76 & 40.35 & 0.846 & 1.61 & 37.46 \\
\hline 50.00 & 8.26 & $40 W$ & 1.45 & 28.67 & 0.934 & 1.59 & 30.98 \\
\hline
\end{tabular}

$D$ Desirability 

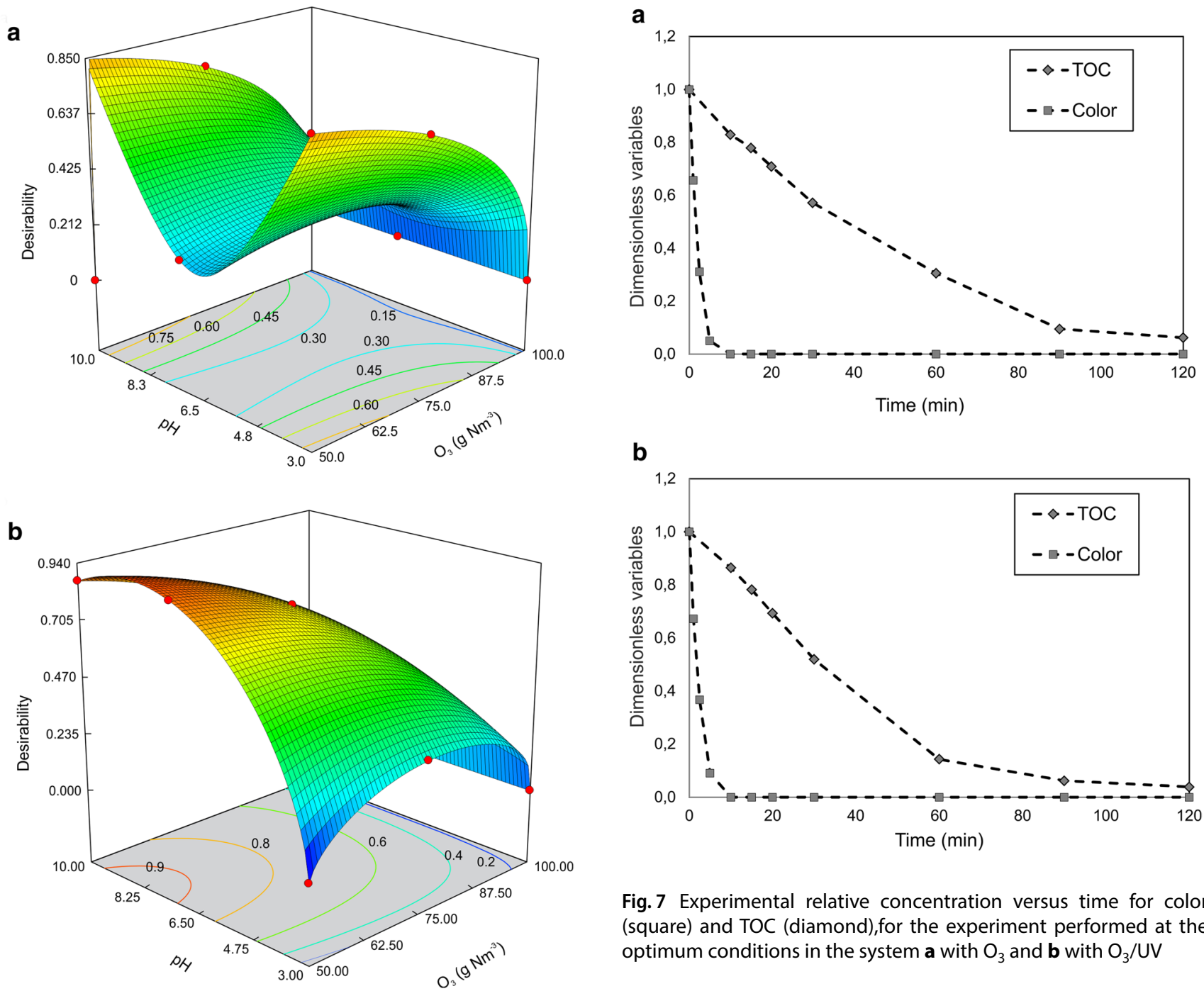

Fig. 7 Experimental relative concentration versus time for color (square) and TOC (diamond),for the experiment performed at the optimum conditions in the system $\mathbf{a}$ with $\mathrm{O}_{3}$ and $\mathbf{b}$ with $\mathrm{O}_{3} / \mathrm{UV}$

Fig. 6 Graph of desirability for a system without UV radiation b system with UV radiation

\section{Conclusions}

In this study, response surface methodology (RSM) using two factorial designs was applied to model the ozonation process and to evaluate the effect of important process variables ( $\mathrm{pH}$, Ozone concentration, UV radiation) on the decolorization and mineralization half-life time of RB19 anthraquinone dye from aqueous solutions. It was found that color half-life time can be reduced increasing $\mathrm{O}_{3}$ concentration or decreasing $\mathrm{pH}$, and that the presence of UV radiation increases color half-life time. For the case of UV treatment, it can be seen that there is a wide continuous zone under different working conditions, in which one could work obtaining low $\mathrm{TOC}_{1 / 2}$ values. Conversely, for the treatment without UV, the working zone to obtain low value of half-life time are bounded areas and in the

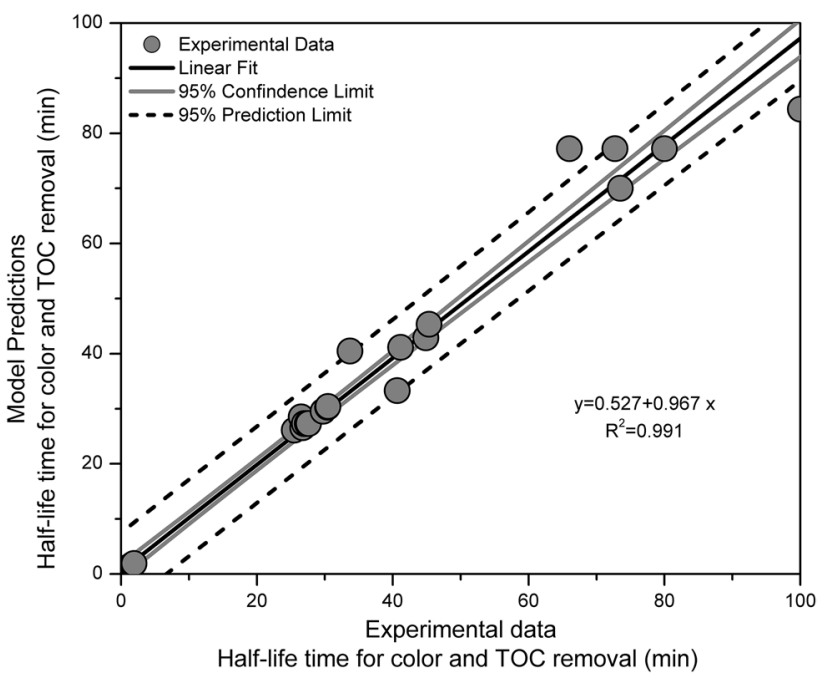

Fig. 8 Experimental values plotted against the predicted values derived from the factorial design resulted equations (Models $Q_{1}$ to $\mathrm{Q}_{4}$ ) 
extreme values of $\mathrm{O}_{3}$ and $\mathrm{pH}$. When the goal is to mineralize the solution, the best conditions for decreasing TOC half-life time are high $\mathrm{O}_{3}$ concentrations, high $\mathrm{pH}$ values and presence of UV radiation. Based on analyses of variance (ANOVA), four quadratic models were proposed, with high coefficients of determination $\left(R^{2}=0.9900,0.9557\right.$, 0.9828 and 0.9994$)$, showing that the experimental data were correctly fitted by the model. The optimum conditions for RB19 mineralization were determined: $\mathrm{O}_{3}$ concentration $=50 \mathrm{mg} \mathrm{L}^{-1}, \mathrm{pH} 8.26$ and presence of UV radiation $(40 \mathrm{~W})$ and subsequently corroborated by means of a specific experimental run. With this system, the operating conditions can move in a safe working range, with similar optimization results. The obtained results confirm ozonation as a promising alternative for treatment of wastewater with a high content of recalcitrant reactive dyes.

Acknowledgements This work was supported by Universidad Nacional del Litoral (Grant No. 50120110100206) and Agencia Nacional de Promoción Científica y Tecnológica (Grant No. PICT 2015-2651).

\section{Compliance with ethical standards}

Conflict of interest On behalf of all authors, the corresponding author states that there is no conflict of interest.

\section{References}

1. Vinu R, Akki SU, Madras G (2010) Investigation of dye functional group on the photocatalytic degradation of dyes by nano- $\mathrm{TiO}_{2}$. J Hazard Mater 176(1-3):765-773

2. Deng D, Guo J, Zeng G, Sun G (2008) Decolorization of anthraquinone, triphenylmethane and azo dyes by a new isolated Bacillus cereus strain DC11. Int Biodeterior Biodegrad 62(3):263-269

3. He Z, Lin L, Song S, Xia M, Xu L, Ying H, Chen J (2008) Mineralization of $\mathrm{Cl}$ Reactive Blue 19 by ozonation combined with sonolysis: performance optimization and degradation mechanism. Sep Purif Technol 62(2):376-381

4. Fanchiang JM, Tseng DH (2009) Degradation of anthraquinone dye $\mathrm{Cl}$ Reactive Blue 19 in aqueous solution by ozonation. Chemosphere 77(2):214-221

5. Novotný Č, Dias N, Kapanen A, Malachová K, Vándrovcová M, Itävaara M, Lima N (2006) Comparative use of bacterial, algal and protozoan tests to study toxicity of azo-and anthraquinone dyes. Chemosphere 63(9):1436-1442

6. Leme DM, Oliveira GARD, Meireles G, Brito LB, Rodrigues LDB, Palma de Oliveira D (2015) Eco-and genotoxicological assessments of two reactive textile dyes. JToxicol Environ Health Part A 78(5):287-300

7. Ansari F, Ghaedi M, Taghdiri M, Asfaram A (2016) Application of $\mathrm{ZnO}$ nanorods loaded on activated carbon for ultrasonic assisted dyes removal: experimental design and derivative spectrophotometry method. Ultrason Sonochem 33:197-209

8. Chidambaram T, Oren Y, Noel M (2015) Fouling of nanofiltration membranes by dyes during brine recovery from textile dye bath wastewater. Chem Eng J 262:156-168
9. Dasgupta J, Sikder J, Chakraborty S, Curcio S, Drioli E (2015) Remediation of textile effluents by membrane based treatment techniques: a state of the art review. J Environ Manag 147:55-72

10. Khandegar V, Saroha AK (2013) Electrocoagulation for the treatment of textile industry effluent-a review. J Environ Manag 128:949-963

11. Benitez FJ, Acero JL, Real FJ, Roman S (2004) Oxidation of MCPA and 2,4-D by UV radiation, ozone, and the combinations UV/ $\mathrm{H}_{2} \mathrm{O}_{2}$ and $\mathrm{O}_{3} / \mathrm{H}_{2} \mathrm{O}_{2}$. J Environ Sci Health Part B 39(3):393-409

12. Lovato $M E$, Martín CA, Cassano AE (2011) A reaction-reactor model for $\mathrm{O}_{3}$ and UVC radiation degradation of dichloroacetic acid: the kinetics of three parallel reactions. Chem Eng J 171(2):474-489

13. Gilliard MB, Martín CA, Cassano AE, Lovato ME (2013) Reaction kinetic model for 2,4-dichlorophenoxyacetic acid decomposition in aqueous media including direct photolysis, direct ozonation, ultraviolet $\mathrm{C}$, and $\mathrm{pH}$ enhancement. Ind Eng Chem Res 52(39):14034-14048

14. Lovato ME, Gilliard MB, Cassano AE, Martín CA (2015) Kinetics of the degradation of n-butyl benzyl phthalate using $\mathrm{O}_{3} / \mathrm{UV}$, direct photolysis, direct ozonation and UV effects. Environ Sci Pollut Res 22(2):909-917

15. Bakheet B, Yuan S, Li Z, Wang H, Zuo J, Komarneni S, Wang $Y$ (2013) Electro-peroxone treatment of Orange II dye wastewater. Water Res 47(16):6234-6243

16. Lovato ME, Martín CA, Cassano AE (2009) A reaction kinetic model for ozone decomposition in aqueous media valid for neutral and acidic pH. Chem Eng J 146(3):486-497

17. Soares OSG, Faria PC, Órfão JJ, Pereira MFR (2007) Ozonation of textile effluents and dye solutions in the presence of activated carbon under continuous operation. Sep Sci Technol 42(7):1477-1492

18. Hassan MM, Hawkyard CJ, Barratt PA (2006) Decolourisation of dyes and dyehouse effluent in a bubble-column reactor by ozonation in the presence of $\mathrm{H}_{2} \mathrm{O}_{2}, \mathrm{KMnO}_{4}$ or Ferral. J Chem Technol Biotechnol 81(2):158-166

19. Özbelge TA, Erol F (2008) Effects of $\mathrm{pH}$, initiator, scavenger, and surfactant on the ozonation mechanism of an azo dye (acid red151) in a batch reactor. Chem Eng Commun 196(1-2):39-55

20. Lovato ME, Fiasconaro ML, Martín CA (2017) Degradation and toxicity depletion of RB19 anthraquinone dye in water by ozone-based technologies. Water Sci Technol 75(4):813-822

21. Debnath S, Ballav N, Nyoni H, Maity A, Pillay K (2015) Optimization and mechanism elucidation of the catalytic photo-degradation of the dyes Eosin Yellow (EY) and Naphthol blue black (NBB) by a polyaniline-coated titanium dioxide nanocomposite. Appl Catal B 163:330-342

22. Vaiano V, Sacco O, Sannino D, Ciambelli P (2015) Nanostructured $\mathrm{N}$-doped $\mathrm{TiO}_{2}$ coated on glass spheres for the photocatalytic removal of organic dyes under UV or visible light irradiation. Appl Catal B 170:153-161

23. Li H, Li Y, Xiang L, Huang Q, Qiu J, Zhang H, Sivaiah MV, Baron F, Barrault J, Petit S, Valange S, Valange S (2015) Heterogeneous photo-Fenton decolorization of Orange II over Al-pillared Fesmectite: response surface approach, degradation pathway, and toxicity evaluation. J Hazard Mater 287:32-41

24. Da Silva Leite $L$, de Souza Maselli B, de Aragão Umbuzeiro G, Nogueira RFP (2016) Monitoring ecotoxicity of disperse red 1 dye during photo-Fenton degradation. Chemosphere 148:511-517

25. Rauf MA, Ali L, Sadig MSAY, Ashraf SS, Hisaindee S (2016) Comparative degradation studies of Malachite Green and Thiazole Yellow $\mathrm{G}$ and their binary mixture using $\mathrm{UV} / \mathrm{H}_{2} \mathrm{O}_{2}$. Desalin Water Treat 57(18):8336-8342

26. Siddique M, Farooq R, Khan ZM, Khan Z, Shaukat SF (2011) Enhanced decomposition of reactive blue 19 dye in 
ultrasound assisted electrochemical reactor. Ultrason Sonochem 18(1):190-196

27. Chen TY, Kao CM, Hong A, Lin CE, Liang SH (2009) Application of ozone on the decolorization of reactive dyes-Orange-13 and Blue-19. Desalination 249(3):1238-1242

28. Guimarães JR, Maniero MG, de Araújo RN (2012) A comparative study on the degradation of RB-19 dye in an aqueous medium by advanced oxidation processes. J Environ Manag 110:33-39

29. Liu BW, Chou MS, Kao CM, Huang BJ (2004) Evaluation of selected operational parameters for the decolorization of dye-finishing wastewater using UV/ozone. Ozone Sci Eng 26(3):239-245

30. Mukimin A, Wijaya K, Kuncaka A (2012) Oxidation of remazol brilliant blue $r$ (RB. 19) with in situ electro-generated active chlorine using $\mathrm{Ti} / \mathrm{PbO}_{2}$ electrode. Sep Purif Technol 95:1-9

31. Lall R, Mutharasan R, Shah YT, Dhurjati P (2003) Decolorization of the dye, reactive blue 19, using ozonation, ultrasound, and ultrasound-enhanced ozonation. Water Environ Res 75(2):171-179

32. Hsu YC, Chen YF, Chen JH (2004) Decolorization of dye RB-19 solution in a continuous ozone process. J Environ Sci Health Part A Toxic/Hazard Subst Environ Eng 39(1):127-144

33. Song S, Xu X, Xu L, He Z, Ying H, Chen J, Yan B (2008) Mineralization of $\mathrm{Cl}$ Reactive Yellow 145 in aqueous solution by ultravioletenhanced ozonation. Ind Eng Chem Res 47(5):1386-1391

34. Tehrani-Bagha AR, Mahmoodi NM, Menger FM (2010) Degradation of a persistent organic dye from colored textile wastewater by ozonation. Desalination 260(1-3):34-38

35. Montgomery DC (2013) Design and analysis of experiments. Wiley, New York

36. Isa MH (2015) Simulated textile dye wastewater treatment by electrochemical oxidation: application of response surface methodology (RSM). Desalin Water Treat 53(8):2260-2265

37. Moradi M, Eslami A, Ghanbari F (2016) Direct Blue 71 removal by electrocoagulation sludge recycling in photo-Fenton process: response surface modeling and optimization. Desalin Water Treat 57(10):4659-4670

38. Akay U, Demirtas EA (2015) Degradation of burazol blue ED by heterogeneous fenton process: simultaneous optimization by central composite design. Desalin Water Treat 56(12):3346-3356

39. Pillai IMS, Gupta AK, Tiwari MK (2015) Multivariate optimization for electrochemical oxidation of methyl orange: pathway identification and toxicity analysis. J Environ Sci Health Part A Toxic/ Hazard Subst Environ Eng 50(3):301-310
40. Im JK, Cho IH, Kim SK, Zoh KD (2012) Optimization of carbamazepine removal in $\mathrm{O}_{3} / \mathrm{UV} / \mathrm{H}_{2} \mathrm{O}_{2}$ system using a response surface methodology with central composite design. Desalination 285:306-314

41. Vedaraman N, Begum SS, Srinivasan SV (2013) Response surface methodology for decolourisation of leather dye using ozonation in a packed bed reactor. Clean Technol Environ Policy 15(4):607-616

42. Chianeh FN, Parsa JB (2014) Degradation of azo dye from aqueous solutions using nano- $\mathrm{SnO}_{2} / \mathrm{Ti}$ electrode prepared by electrophoretic deposition method: experimental design. Chem Eng Res Des 92(11):2740-2748

43. Arslan A, Veli S, Bingöl D (2014) Use of response surface methodology for pretreatment of hospital wastewater by $\mathrm{O}_{3} / \mathrm{UV}$ and $\mathrm{O}_{3} / \mathrm{UV} / \mathrm{H}_{2} \mathrm{O}_{2}$ processes. Sep Purif Technol 132:561-567

44. Jiao W, Yu L, Feng Z, Guo L, Wang Y, Liu Y (2016) Optimization of nitrobenzene wastewater treatment with $\mathrm{O}_{3} / \mathrm{H}_{2} \mathrm{O}_{2}$ in a rotating packed bed using response surface methodology. Desalin Water Treatt 57(42):19996-20004

45. Souza FS, Féris LA (2015) Degradation of caffeine by advanced oxidative processes: $\mathrm{O}_{3}$ and $\mathrm{O}_{3} / \mathrm{UV}$. Ozone Sci Eng 37(4):379-384

46. Mehrizad A, Gharbani P (2016) Application of central composite design and artificial neural network in modeling of reactive blue 21 dye removal by photo-ozonation process. Water Sci Technol 74(1):184-193

47. Candioti LV, De Zan MM, Cámara MS, Goicoechea HC (2014) Experimental design and multiple response optimization. Using the desirability function in analytical methods development. Talanta 124:123-138

48. Beltran FJ (2003) Ozone reaction kinetics for water and wastewater systems. Lewis Publ CRC Press, Boca Raton

49. Panda KK, Mathews AP (2014) Ozone oxidation kinetics of Reactive Blue 19 anthraquinone dye in a tubular in situ ozone generator and reactor: modeling and sensitivity analyses. Chem Eng J 255:553-567

Publisher's Note Springer Nature remains neutral with regard to jurisdictional claims in published maps and institutional affiliations. 